\title{
Subunit-Dependent Modulation of Neuronal Nicotinic Receptors by Zinc
}

\author{
Bernard Hsiao, David Dweck, and Charles W. Luetje \\ Department of Molecular and Cellular Pharmacology, University of Miami School of Medicine, Miami, Florida 33101
}

We examined the effect of zinc on rat neuronal nicotinic acetylcholine receptors (nAChRs) expressed in Xenopus oocytes as simple heteromers of $\alpha 2, \alpha 3$, or $\alpha 4$ and $\beta 2$ or $\beta 4$. Coapplication of zinc with low concentrations of acetylcholine $\left(\leq \mathrm{EC}_{10}\right)$ resulted in differential effects depending on receptor subunit composition. The $\alpha 2 \beta 2, \alpha 2 \beta 4, \alpha 3 \beta 4, \alpha 4 \beta 2$, and $\alpha 4 \beta 4$ receptors exhibited biphasic modulation by zinc, with potentiation of the acetylcholine response occurring at 1-100 $\mu \mathrm{M}$ zinc and inhibition occurring at higher zinc concentrations. In contrast, $\alpha 3 \beta 2$ receptors were only inhibited by zinc $\left(\mathrm{IC}_{50}=97 \pm 16 \mu \mathrm{M}\right)$. The greatest potentiating effect of zinc was seen with $\alpha 4 \beta 4$ receptors that were potentiated to $560 \pm 17 \%$ of the response to ACh alone, with an $\mathrm{EC}_{50}$ of $22 \pm 4 \mu \mathrm{M}$ zinc. Cadmium, but not nickel, was also able to potentiate $\alpha 4 \beta 4$ receptors. Both zinc potentiation of $\alpha 4 \beta 4$ receptors and zinc inhibition of $\alpha 3 \beta 2$ receptors were voltage independent. The sensitivity of zinc potentiation of $\alpha 4 \beta 4$ to diethylpyrocarbonate treatment and alterations in $\mathrm{pH}$ suggested the involvement of histidine residues. Zinc continued to inhibit $\alpha 4 \beta 4$ and $\alpha 3 \beta 2$ after diethylpyrocarbonate treatment. Application of a potentiating zinc concentration increased the response of $\alpha 4 \beta 2$ and $\alpha 4 \beta 4$ receptors to saturating $\mathrm{ACh}$ concentrations. The rate of Ach-induced desensitization of these receptors was unaffected by zinc. Our results reveal zinc potentiation as a new mode of neuronal nAChR modulation.

Key words: neuronal nicotinic receptors; zinc; potentiation; inhibition; modulation; acetylcholine
Nicotinic acetylcholine receptors (nAChRs) are ligand-gated ion channels found at the neuromuscular junction and throughout the CNS and PNS. Neuronal nAChRs are similar to muscle nAChRs: they are formed as pentameric assemblies of subunits (Anand et al., 1991; Cooper et al., 1991). To date, the neuronal nAChR subunit family consists of nine $\alpha$ subunits $(\alpha 2-\alpha 10)$ and three $\beta$ subunits $(\beta 2-\beta 4)$ (Corringer et al., 2000). These subunits can assemble, in exogenous expression systems, in various combinations to form receptors with varying functional and pharmacological properties (Role, 1992). In the nervous system, neuronal $\mathrm{nAChRs}$ can form as pentameric homomers (such as $\alpha 7$ receptors) (Chen and Patrick, 1997; Drisdel and Green, 2000), as simple heteromers composed of a single type of $\alpha$ subunit and a single type of $\beta$ subunit (such as $\alpha 4 \beta 2$ receptors) (Whiting et al., 1991; Flores et al., 1992), or as complex heteromers of three or more subunits (such as $\alpha 3 \alpha 5 \beta 4$ receptors) (Conroy and Berg, 1995).

Ionic zinc has been found in neurons throughout the brain, with highest concentrations in the cerebral cortex and limbic areas (Frederickson et al., 2000). Zinc is localized to small, clear vesicles in synaptic terminals and is released in a calciumdependent manner (Assaf and Chung, 1984; Howell et al., 1984). The extracellular concentration of zinc is estimated to reach concentrations as high as $300 \mu \mathrm{M}$ (Assaf and Chung, 1984). Zinc

Received Oct. 2, 2000; revised Dec. 14, 2000; accepted Dec. 22, 2000.

This work was supported by a grant to C.W.L. from the National Institute on Drug Abuse (DA08102). B.H. and D.D. were supported in part by National Heart, Lung, and Blood Institute T32HL07188. B.H. was supported in part by a PhRMA Foundation Medical Student Research Fellowship. B.H. is a Lois Pope LIFE Fellow. We thank Drs. Richard Kramer and Jeff Krajewski for helpful discussions and Ana Mederos for technical assistance.

Correspondence should be addressed to Dr. Charles W. Luetje, Department of Molecular and Cellular Pharmacology (R-189), University of Miami School of Medicine, P.O. Box 016189, Miami, FL 33101. E-mail: cluetje@chroma.med.miami.edu. Copyright (C) 2001 Society for Neuroscience $0270-6474 / 01 / 211848-09 \$ 15.00 / 0$ modulates the functions of members of several ligand-gated ion channel families, including glutamate, GABA, glycine, and ATP receptors (Mayer et al., 1989; Draguhn et al., 1990; Rassendren et al., 1990; Cloues et al., 1993; Bloomenthal et al., 1994; Paoletti et al., 1997; Krishek et al., 1998; Harvey et al., 1999; Xiong et al., 1999; Laube et al., 2000). Both potentiation and inhibition of agonist-induced responses have been observed. The ability to modulate ligand-gated ion channel function suggests that zinc may be an important modulator of synaptic activity.

Relatively few studies have examined the effect of zinc on neuronal nAChRs. Zinc was shown to block ACh responses of rat intracardiac parasympathetic neurons (Nutter and Adams, 1995). Zinc also attenuates the Ach-induced response of homomeric $\alpha 7$ nAChRs exogenously expressed in Xenopus oocytes (Palma et al., 1998). We have now examined the effect of zinc on the several neuronal nAChRs that can be formed by pairwise expression of the $\alpha 2, \alpha 3$, or $\alpha 4$ subunits with the $\beta 2$ or $\beta 4$ subunits in Xenopus oocytes. We find that although all subunit combinations are inhibited by high concentrations of zinc, some subunit combinations are potentiated by low zinc concentrations $(\leq 100 \mu \mathrm{M})$. Moreover, the extent of potentiation by zinc varies markedly depending on receptor subunit composition. Potentiation by zinc represents a new mode of neuronal $\mathrm{nAChR}$ modulation.

\section{MATERIALS AND METHODS}

Materials. Xenopus laevis frogs were purchased from Nasco (Fort Atkinson, WI). The care and use of $X$. laevis frogs in this study were approved by the University of Miami Animal Research Committee and meet the guidelines of the National Institutes of Health. RNA transcription kits were from Ambion (Austin, TX). Collagenase B was from Boehringer Mannheim (Indianapolis, IN). All other reagents were from Sigma (St. Louis, MO).

Neuronal $n A C h R$ expression in $\mathrm{X}$. laevis oocytes. $\mathrm{m}^{7} \mathrm{G}\left(5^{\prime}\right) \mathrm{ppp}\left(5^{\prime}\right) \mathrm{G}-$ capped cRNA transcripts encoding nAChR subunits were prepared by in vitro transcription from linearized template DNA encoding the $\alpha 2, \alpha 3$, 
$\alpha 4, \beta 2, \beta 4, \alpha 3-216-\alpha 4$, and $\alpha 4-216-\alpha 3$ subunits. Chimeric subunits were constructed previously (Harvey et al., 1996). Mature $X$. laevis frogs were anesthetized by submersion in $0.1 \% 3$-aminobenzoic acid ethyl ester, and oocytes were surgically removed. Follicle cells were removed by treatment with collagenase B for $2 \mathrm{hr}$ at room temperature. Stage V oocytes were individually injected with $0.5-10 \mathrm{ng}$ of each cRNA in 15-50 nl of water and incubated at $19^{\circ} \mathrm{C}$ in modified Barth's saline $(88 \mathrm{~mm} \mathrm{NaCl}, 1$ mM KCl, $2.4 \mathrm{~mm} \mathrm{NaHCO} 3,0.3 \mathrm{~mm} \mathrm{CaNO}_{3}, 0.41 \mathrm{~mm} \mathrm{CaCl}_{2}, 0.82 \mathrm{~mm}$ $\mathrm{MgSO}_{4}, 100 \mu \mathrm{g} / \mathrm{ml}$ gentamicin, $15 \mathrm{~mm}$ HEPES, pH 7.6) for 2-7 $\mathrm{d}$.

Electrophysiological methods. Current responses were measured under two-electrode voltage clamp, using a TEV-200 voltage-clamp unit (Dagan, Minneapolis, MN). Micropipettes were filled with $3 \mathrm{M} \mathrm{KCl}$ and had resistances of 0.3-2.0 M $\Omega$. Current responses were sampled at $100 \mathrm{~Hz}$ and filtered (four-pole, Bessel low-pass) at $20 \mathrm{~Hz}$. Current responses were captured, stored, and analyzed on a Macintosh Power PC 7100 computer using AxoData 1.2.2 and AxoGraph 4.0 software (Axon Instruments, Foster City, CA). All experiments were performed at a holding potential of $-70 \mathrm{mV}$, except for voltage-dependence studies (see Fig. 7), ACh concentration-response experiments (see Fig. 8), and desensitization rate measurements. The ACh concentration-response experiments were performed at a holding potential of $-40 \mathrm{mV}$ to decrease current amplitudes at higher ACh concentrations and to minimize the contribution of the calcium-activated chloride channel to the $\mathrm{ACh}$ response. As demonstrated in Figure 7, the $\mathrm{Zn}^{2+}$ effect is independent of membrane holding potential. Desensitization rate measurements for $\alpha 4 \beta 4$ and $\alpha 4 \beta 2$ receptors were performed at $-40 \mathrm{mV}$ with $\mathrm{Ba}^{2+}$ substituting for $\mathrm{Ca}^{2+}$ in all solutions to further minimize any contribution of the calcium-activated chloride channels. Each oocyte was exposed to an $\mathrm{EC}_{50}$ concentration of $\mathrm{ACh}$ with or without $50 \mu \mathrm{M} \mathrm{Zn^{2+ }}$ for $60 \mathrm{sec}$. The order of application was alternated from oocyte to oocyte. The desensitizing phase of each response was fit to a single exponential function.

Oocytes were perfused at room temperature $\left(20-25^{\circ} \mathrm{C}\right)$ with perfusion solution (115 mM NaCl, $1.8 \mathrm{~mm} \mathrm{CaCl}_{2}, 2.5 \mathrm{~mm} \mathrm{KCl,} 0.1 \mu \mathrm{M}$ atropine, $10 \mathrm{mM}$ HEPES, pH 7.2) in a chamber constructed from 1/8 inch inner diameter Tygon tubing. Perfusion was continuous at a rate of $\sim 20$ $\mathrm{ml} / \mathrm{min}$. Agonists and metals were diluted in the perfusion solution and then applied to oocytes using solenoid valves. All experiments, except for desensitization rate measurements and experiments shown in Figs. 3 and 8 , were performed as follows. ACh alone was applied for $30 \mathrm{sec}$, followed by a $30 \mathrm{sec}$ application of solutions containing both $\mathrm{ACh}$ and the metal ion of interest, and then by $30 \mathrm{sec}$ of $\mathrm{ACh}$ alone. Between applications, oocytes were perfused continuously. In cases in which no desensitization was evident ( $\alpha 4 \beta 4$ responses in Figs. $1-7)$, defined as a current decrease of $<5 \%$ over $30 \mathrm{sec}$, control current in response to agonist was determined from a $1 \mathrm{sec}$ average beginning $29 \mathrm{sec}$ after initiation of agonist application. Current levels during metal coapplication were determined from a $1 \mathrm{sec}$ average beginning $29 \mathrm{sec}$ after initiation of metal application and compared with the control current. In cases in which desensitization was evident (all experiments involving $\alpha 2 \beta 2, \alpha 2 \beta 4, \alpha 3 \beta 2, \alpha 3 \beta 4$, and $\alpha 4 \beta 2$ ), defined as a current decrease of $>5 \%$ over $30 \mathrm{sec}$, the following analysis method was used. The initial $30 \mathrm{sec} \mathrm{ACh}$ response in the absence of metal was fit to a single or dual exponential and was projected over the next $30 \mathrm{sec}$ in which both $\mathrm{ACh}$ and metal were coapplied. The degree of modulation was measured by taking a $1 \mathrm{sec}$ average $29 \mathrm{sec}$ after initiation of metal application and comparing it with a $1 \mathrm{sec}$ average of the projected response to $\mathrm{ACh}$ alone at the same time period. Thus, both metal and control values were taken $59 \mathrm{sec}$ after the initiation of the experiment.

For the ACh concentration-response experiments shown in Figure 8, experiments were performed and measurements were taken as follows. Because receptor expression levels vary from oocyte to oocyte, it is necessary to normalize concentration-response data from different oocytes to allow comparison. However, desensitization makes the maximal response an unreliable standard with which to normalize data. For this reason we normalized each response to the response to a low concentration of $\mathrm{ACh}(3 \mu \mathrm{M})$ that produced little or no desensitization. To compare and display the results we then renormalized the data to the fit maximal response to $\mathrm{ACh}$ alone. To determine the effect of $\mathrm{Zn}^{2+}$ on the ACh concentration-response relationship we used our standard protocol (30 sec of $\mathrm{ACh}$ alone, followed by $30 \mathrm{sec}$ of $\mathrm{ACh}+\mathrm{Zn}^{2+}$, followed by 30 sec of ACh alone), but with a normalizing ACh application interleaved between experimental applications. Data were then normalized to the immediately preceding application of $3 \mu \mathrm{M} \mathrm{ACh}$. We measured the effect of $\mathrm{Zn}^{2+}$ in two ways. First, because most responses of both receptors showed appreciable desensitization, we measured the effect of $\mathrm{Zn}^{2+}$ as described above for desensitizing receptors. Second, the peak response to $\mathrm{Zn}^{2+}$ was compared with a $1 \mathrm{sec}$ average of the response to $\mathrm{ACh}$ alone taken immediately before $\mathrm{Zn}^{2+}$ application. Because both methods yielded similar results, only the results of the first method are plotted in Figure 8.

Because neuronal nAChRs differ in their sensitivity to ACh, it is important to ensure that the effects of metal application are measured with ACh concentrations that elicit a similar fraction of the maximal response. Therefore, unless noted otherwise, all $\mathrm{ACh}$ concentrations were within a range from the $\mathrm{EC}_{2}$ to the $\mathrm{EC}_{10}$ for each receptor. $\mathrm{ACh}$ $\mathrm{EC}_{2}$ and $\mathrm{EC}_{10}$ values were calculated from data presented previously (Harvey et al., 1996). Within this range, a single ACh concentration was used for each subunit combination (12 $\mu \mathrm{M}$ for $\alpha 2 \beta 2,15 \mu \mathrm{M}$ for $\alpha 2 \beta 4,4$ $\mu \mathrm{M}$ for $\alpha 3 \beta 2,17 \mu \mathrm{M}$ for $\alpha 3 \beta 4,10 \mu \mathrm{M}$ for $\alpha 4 \beta 2,1 \mu \mathrm{M}$ for $\alpha 4 \beta 4$ ).

Zinc solutions used in all experiments shown in this study were prepared from zinc acetate stock solutions. To rule out an effect of the acetate, zinc concentration effect curves for the $\alpha 3 \beta 2, \alpha 4 \beta 2$, and $\alpha 4 \beta 4$ receptors were replicated using $\mathrm{ZnCl}_{2}$ with similar results (data not shown). In the absence of $\mathrm{ACh}$, zinc concentrations $<70 \mu \mathrm{M}$ had no effect on $\alpha 4 \beta 4$-expressing, $\alpha 3 \beta 2$-expressing, or uninjected oocytes. Zinc concentrations $\geq 70 \mu \mathrm{M}$ elicited small, slow, variable (inward and outward) currents. Because these currents were always $<5 \%$ of ACh responses, they were disregarded in our analysis.

Diethylpyrocarbonate treatment of $n A C h R s$. Diethylpyrocarbonate (DEPC) was diluted in perfusion solution immediately before application. Preliminary experiments determined that a $10 \mathrm{~min}$ incubation achieved a maximal DEPC effect (data not shown). During incubation, the DEPC solution was exchanged twice at regular intervals. After incubation, the DEPC was washed out of the chamber for an additional 10 min with perfusion solution. Electrophysiological measurements were taken before DEPC application and immediately after the 10 min washout period.

Data analysis. Data from metal concentration-response experiments for $\alpha 2 \beta 2, \alpha 2 \beta 4, \alpha 3 \beta 4, \alpha 4 \beta 2$, and $\alpha 4 \beta 4$ receptors were analyzed as follows. Concentration-potentiation curves were fit according to the following equation for concentrations up to and including those concentrations of metals that achieved maximal potentiation: $I=I_{\max } /(1+$ $\left.\left(\mathrm{EC}_{50} / X\right)^{\mathrm{n}}\right)$, where $I$ represents the current response at a given metal concentration, $X ; I_{\max }$ is the maximal current; $\mathrm{EC}_{50}$ is the concentration of metal yielding half-maximal potentiation; $\mathrm{n}$ is the Hill coefficient. Concentration-inhibition curves were fit according to the following equation for concentrations of metals at or above those concentrations that achieved maximal potentiation: $I=I_{\max } /\left(1+\left(X / \mathrm{IC}_{50}\right)^{\mathrm{n}}\right)$, where $I$ represents the current response at a given metal concentration, $X ; I_{\max }$ is the maximal current; $\mathrm{IC}_{50}$ is the concentrations of metal yielding halfmaximal inhibition; $n$ is the Hill coefficient. Because no potentiation was apparent for the $\alpha 3 \beta 2$ receptor, the entire data set was fit with the concentration-inhibition equation.

The data presented in Figure 2 suggest that at some concentrations zinc may be exerting both potentiating and inhibiting effects on neuronal nAChRs. If this is true, then the maximal potentiation that we observe may be an underestimate. To examine this issue, we fit the zinc concentration-effect data to a more complex equation that included both a potentiating and an inhibitory site: $I=I_{\min }+\left(\mathrm{I}_{\max }-\mathrm{I}_{\min }\right)\{[1 /(1+$ $\left.\left.\left.\left(\mathrm{EC}_{50} / X\right)^{\mathrm{n}}\right)\right]-\left[1 /\left(1+\left(\mathrm{IC}_{50} / X\right)^{\mathrm{m}}\right)\right]\right\}$, where $I$ represents the current response at a given metal concentration, $X ; I_{\min }$ is the minimal current; $I_{\max }$ is the maximal current; $\mathrm{EC}_{50}$ and $\mathrm{IC}_{50}$ are the concentrations of metal yielding half-maximal potentiation and inhibition, respectively; $n$ and $\mathrm{m}$ are the Hill coefficients for potentiation and inhibition, respectively (Harvey et al., 1999). Results of this analysis suggest that the maximal potentiation that we observe is indeed an underestimate. Fitting to this equation suggests that the true maximal potentiation is severalfold greater than what we observe. However, because the measured data covers only the lower portion of the putative full curve, we have reported only the results of fitting the potentiating and inhibiting data sets separately.

ACh concentration-response curves in Figure 8 were fit to the following equation: $I=I_{\max } /\left(1+\left(\mathrm{EC}_{50} / X\right)^{\mathrm{n}}\right)$, where $I$ represents the current response at a given ACh concentration, $X ; I_{\max }$ is the maximal current; $\mathrm{EC}_{50}$ is the concentration of ACh yielding half-maximal response; $\mathrm{n}$ is the Hill coefficient.

Prism software (GraphPad, San Diego, CA) was used to fit the data and to assess statistical significance using a two-tailed unpaired $t$ test. 




Figure 1. $\mathrm{Zn}^{2+}$ potentiates and inhibits neuronal nAChRs. $A$, Current responses of an $\alpha 4 \beta 2$-expressing oocyte to $10 \mu \mathrm{M}$ ACh before, during, and after coapplication of $70 \mu \mathrm{M}$ (top trace) or $1 \mathrm{mM} \mathrm{Zn}^{2+}$ (bottom trace). Calibration: $60 \mathrm{nA}, 20 \mathrm{sec} . B$, Current responses of an $\alpha 3 \beta 2$-expressing oocyte to $4 \mu \mathrm{M}$ ACh before, during, and after coapplication of $70 \mu \mathrm{M}$ $\mathrm{Zn}^{2+}$ (top trace) or $1 \mathrm{mM} \mathrm{Zn}^{2+}$ (bottom trace). Calibration: $300 \mathrm{nA}, 20$ sec. $C$, Current responses of an $\alpha 4 \beta 4$-expressing oocyte to $1 \mu \mathrm{M} \mathrm{ACh}$ before, during, and after coapplication of $100 \mu \mathrm{M} \mathrm{Zn^{2+ }}$ (top trace) or 3 $\mathrm{mm} \mathrm{Zn}^{2+}$ (bottom trace). Calibration: $200 \mathrm{nA}, 20 \mathrm{sec}$.

\section{RESULTS}

\section{$\mathrm{Zn}^{2+}$ modulates neuronal nAChRs}

Simple heteromeric neuronal nAChRs consisting of one type of $\alpha$ subunit $(\alpha 2, \alpha 3$, or $\alpha 4)$ and one type of $\beta$ subunit ( $\beta 2$ or $\beta 4)$ were expressed in Xenopus oocytes. Current responses were recorded under two-electrode voltage clamp on application of ACh (at or below the $\mathrm{EC}_{10}$ for each receptor) in the absence or presence of various concentrations of $\mathrm{Zn}^{2+}$. The effect of $\mathrm{Zn}^{2+}$ varied depending on the subunit composition of the receptor.

$\mathrm{Zn}^{2+}$ application had a biphasic effect on ACh responses of $\alpha 4 \beta 2$-expressing oocytes. $\mathrm{Zn}^{2+}$ concentrations in the range of 1-100 $\mu \mathrm{M}$ increased the inward current elicited by $10 \mu \mathrm{M} \mathrm{ACh}$ (Figs. $1 A$, top trace, $2 C$ ). A maximal potentiation of $260 \pm 17 \%$

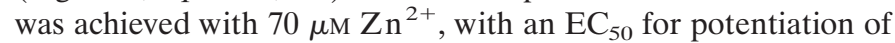
$16 \pm 4 \mu \mathrm{M} \mathrm{Zn}{ }^{2+}$. At higher $\mathrm{Zn}^{2+}$ concentrations, the degree of potentiation by $\mathrm{Zn}^{2+}$ was diminished until at $1 \mathrm{~mm} \mathrm{Zn}^{2+}$, steady current in response to $\mathrm{ACh}+\mathrm{Zn}^{2+}$ was less than current in response to $\mathrm{ACh}$ alone (Figs. $1 A$, bottom trace, $2 C$ ). This apparent inhibition of $\alpha 4 \beta 2$ receptors by $\mathrm{Zn}^{2+}$ had an $\mathrm{IC}_{50}$ of $440 \pm$ $140 \mu \mathrm{M}$.

In contrast to the biphasic effect of $\mathrm{Zn}^{2+}$ on $\alpha 4 \beta 2 \mathrm{nAChRs}$, $\alpha 3 \beta 2$ receptors exhibited only inhibition by $\mathrm{Zn}^{2+}$ (Fig. $1 B, 2 B$ ). Reduction in the current elicited by $4 \mu \mathrm{M}$ ACh occurred with
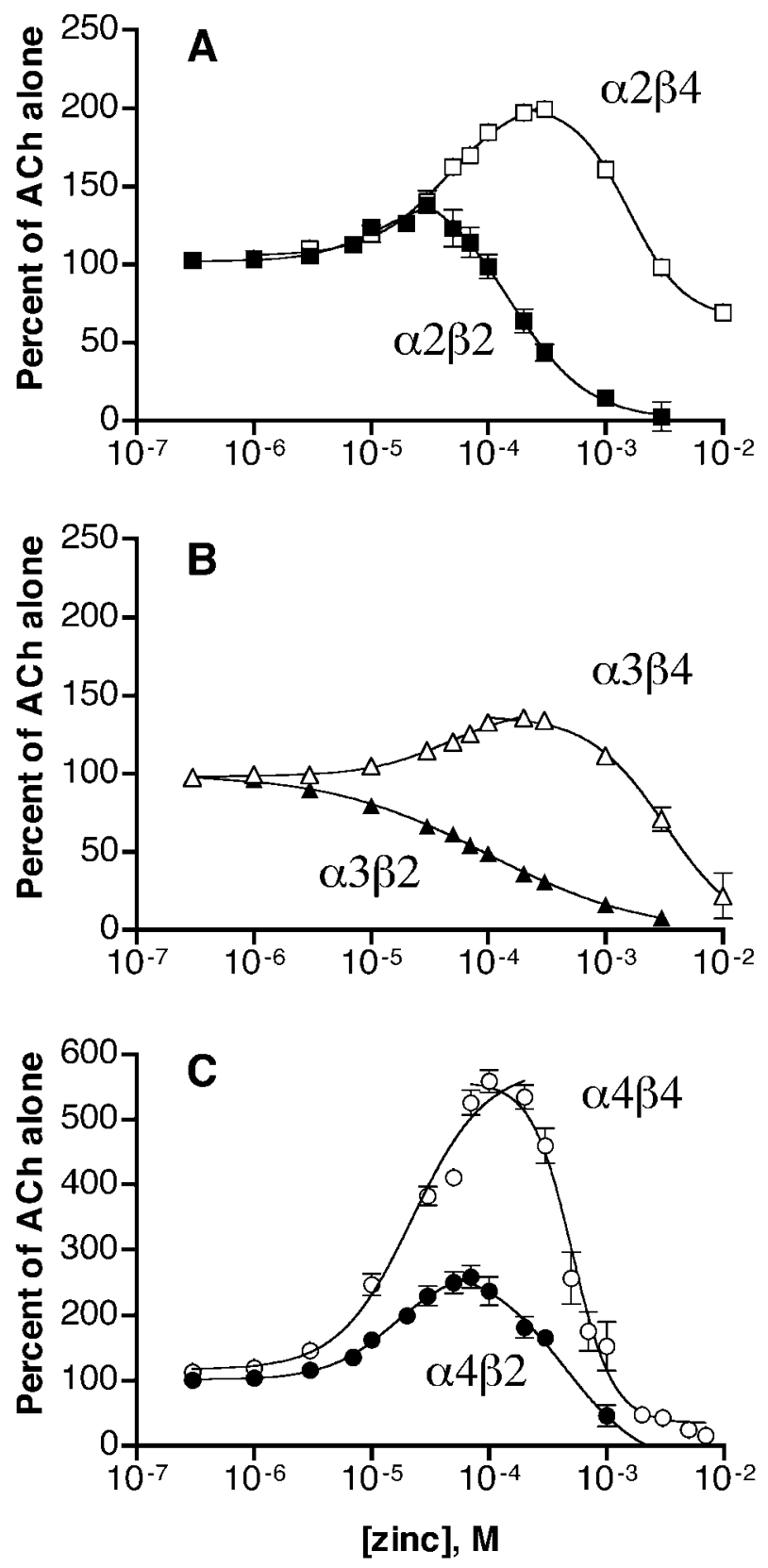

Figure 2. The nature of neuronal $\mathrm{nAChR}$ modulation by $\mathrm{Zn}^{2+}$ is subunit dependent. The effects of $\mathrm{Zn}^{2+}$ coapplication on Ach-induced current responses are plotted as a percentage of the response to ACh alone (mean \pm SEM of 3-6 oocytes). Some error bars are obscured by the symbols. The potentiating and inhibiting phases of the $\mathrm{Zn}^{2+}$ effect were fit separately as described in Materials and Methods. Note the increase in axis range in $C$ to accommodate the greater potentiation seen with $\alpha 4 \beta 4$ nAChRs.

$\mathrm{Zn}^{2+}$ concentrations ranging from $1 \mu \mathrm{M}$ to $3 \mathrm{~mm}$, with an $\mathrm{IC}_{50}$ of $97 \pm 16 \mu \mathrm{M}$. $\mathrm{Zn}^{2+}$ concentrations $\geq 1 \mathrm{~mm}$ almost completely blocked the response to ACh. The loss of $\mathrm{Zn}^{2+}$ potentiation on changing the $\alpha$ subunit from $\alpha 4$ to $\alpha 3$ supports a role for the $\alpha$ subunit in mediating potentiation.

To determine whether $\beta$ subunits also play a role in $\mathrm{Zn}^{2+}$ potentiation of nAChRs, we examined the effect of $\mathrm{Zn}^{2+}$ on the $\alpha 3 \beta 4$ receptor (Fig. $2 B$ ). Current in response to $17 \mu \mathrm{M}$ ACh was

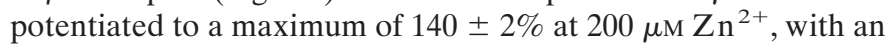
$\mathrm{EC}_{50}$ of $47 \pm 9 \mu \mathrm{M} \mathrm{Zn}{ }^{2+}$. Similar to our results with $\alpha 4 \beta 2$ 
Table 1. Potentiation and inhibition of neuronal nAChRs by $\mathrm{Zn}^{2+}$

\begin{tabular}{|c|c|c|c|c|c|}
\hline \multirow[b]{2}{*}{ Receptor } & \multicolumn{3}{|l|}{ Potentiation } & \multicolumn{2}{|l|}{ Inhibition } \\
\hline & Maximum $(\%)$ & $\mathrm{EC}_{50}(\mu \mathrm{M})$ & $\mathrm{n}_{\mathrm{H}}$ & $\mathrm{IC}_{50}(\mu \mathrm{M})$ & $\mathrm{n}_{\mathrm{H}}$ \\
\hline$\alpha 2 \beta 2$ & $140 \pm 4$ & $13 \pm 7$ & $1.5 \pm 0.7$ & $52 \pm 30$ & $1.3 \pm 0.4$ \\
\hline$\alpha 2 \beta 4$ & $200 \pm 5$ & $45 \pm 6$ & $1.4 \pm 0.2$ & $590 \pm 180$ & $1.8 \pm 0.3$ \\
\hline$\alpha 3 \beta 2$ & & & & $97 \pm 16$ & $0.6 \pm 0.1$ \\
\hline$\alpha 3 \beta 4$ & $140 \pm 2$ & $47 \pm 9$ & $1.2 \pm 0.2$ & $3200 \pm 1400$ & $1.3 \pm 0.6$ \\
\hline$\alpha 4 \beta 2$ & $260 \pm 17$ & $16 \pm 4$ & $1.5 \pm 0.5$ & $440 \pm 140$ & $1.3 \pm 0.6$ \\
\hline$\alpha 4 \beta 4$ & $560 \pm 17$ & $22 \pm 4$ & $1.4 \pm 0.3$ & $510 \pm 37$ & $2.5 \pm 0.4$ \\
\hline$\alpha 3-216-\alpha 4 \beta 4$ & $170 \pm 5$ & $9 \pm 3$ & $1.6 \pm 0.7$ & $1100 \pm 700$ & $1.4 \pm 0.9$ \\
\hline$\alpha 4-216-\alpha 3 \beta 4$ & $250 \pm 10$ & $26 \pm 4$ & $1.6 \pm 0.4$ & $660 \pm 62$ & $2.3 \pm 0.4$ \\
\hline
\end{tabular}



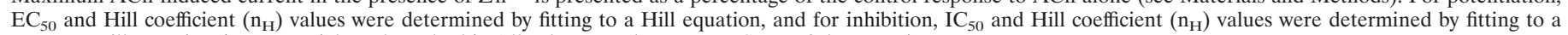
separate Hill equation (see Materials and Methods). All values are the mean \pm SEM of three to six oocytes.

receptors, high concentrations of $\mathrm{Zn}^{2+}$ inhibited the $\alpha 3 \beta 4$ receptor $\left(\mathrm{IC}_{50}=3200 \pm 1400 \mu \mathrm{M} \mathrm{Zn^{2+ }}\right)$.

The ability of $\alpha 4 \beta 2$ and $\alpha 3 \beta 4$, and the failure of $\alpha 3 \beta 2 \mathrm{nAChRs,}$ to be potentiated by $\mathrm{Zn}^{2+}$ suggests that the $\alpha 4$ and $\beta 4$ subunits are each capable of supporting $\mathrm{Zn}^{2+}$ potentiation when they are present in a receptor. When both of these subunits were present in the same receptor $(\alpha 4 \beta 4)$, the effect of $\mathrm{Zn}^{2+}$ was dramatic (Figs. $1 C, 2 C$ ). The $\alpha 4 \beta 4$ receptor was potentiated to a maximum of $560 \pm 17 \%$ at $100 \mu \mathrm{M} \mathrm{Zn}{ }^{2+}$, with an $\mathrm{EC}_{50}$ of $22 \pm 4 \mu \mathrm{M} \mathrm{Zn}{ }^{2+}$. Again, higher concentrations of $\mathrm{Zn}^{2+}$ were found to be inhibi-

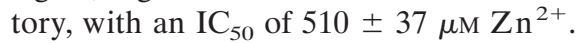

The $\alpha 2$ subunit is highly homologous to the $\alpha 4$ subunit. As might be expected, $\alpha 2 \beta 2$ and $\alpha 2 \beta 4$ receptors were also potentiated by low $\mathrm{Zn}^{2+}$ concentrations and inhibited by high $\mathrm{Zn}^{2+}$ concentrations (Fig. 2A; Table 1 ).

When high concentrations of $\mathrm{Zn}^{2+}$ are coapplied with $\mathrm{ACh}$ to some subunit combinations, the current responses can be complex. A good example can be seen when $3 \mathrm{~mm} \mathrm{Zn}^{2+}$ is coapplied to the $\alpha 4 \beta 4$ receptor (Fig. $1 C$, bottom trace). On coapplication of $\mathrm{Zn}^{2+}$, a rapid transient potentiation is seen, followed by a rapid decrease in the response. On removal of $\mathrm{Zn}^{2+}$, there is again a rapid potentiation of the current followed by a slow decline toward the response amplitude seen with ACh alone. These potentiation transients can be explained by considering the relatively slow fluid exchange rate in the perfusion chamber. When a high concentration of $\mathrm{Zn}^{2+}$ is applied, the concentration of $\mathrm{Zn}^{2+}$ in the chamber will pass through a concentration range that potentiates but does not inhibit the receptors, before reaching a final concentration that both potentiates and inhibits the receptors. Similarly, when $\mathrm{Zn}^{2+}$ is withdrawn, the declining concentration in the chamber will again pass through a potentiating, but not inhibiting, concentration range. To determine whether this explanation is valid, we used a revised protocol in which $\mathrm{Zn}^{2+}$ alone was applied to $\alpha 4 \beta 4$-expressing oocytes first, followed by coapplication of $\mathrm{Zn}^{2+}$ and ACh. With this protocol, the potentiation transients were eliminated (Fig. $3 A$ ). The $\mathrm{Zn}^{2+}$ concentration-effect relationship obtained with this modified protocol (Fig. $3 B$ ) was similar to results presented in Figure $2 C$.

\section{Modulation of nAChRs by cadmium and nickel}

We explored the selectivity of the potentiation by examining the effect of additional transition metals on the $\alpha 4 \beta 4$ receptor (Fig. 4). $\mathrm{Cd}^{2+}$ was able to potentiate $\alpha 4 \beta 4$ receptors with a maximal potentiation to $250 \pm 26 \%$ and an $\mathrm{EC}_{50}$ of $45 \pm 24 \mu \mathrm{M} \mathrm{Cd}^{2+}$. At $1 \mathrm{mM} \mathrm{Cd}^{2+}$ the potentiation was diminished, and at $3 \mathrm{~mm} \mathrm{Cd}^{2+}$


Figure 3. $\mathrm{Zn}^{2+}$ preincubation eliminates potentiation transients seen with high $\mathrm{Zn}^{2+}$ concentrations. $A$, Current responses of an $\alpha 4 \beta 4-$ expressing oocyte preincubated with $0,100 \mu \mathrm{M}$, and $1 \mathrm{mM} \mathrm{Zn}^{2+}$ for $20-30$ sec before coapplication of $1 \mu \mathrm{M}$ ACh. Calibration: $50 \mathrm{nA}, 10 \mathrm{sec} . B$, Current responses during coapplication of various concentrations of $\mathrm{Zn}^{2+}$ and $1 \mu \mathrm{M}$ ACh were plotted as a percentage of the response to $1 \mu \mathrm{M}$ $\mathrm{ACh}$ alone recorded immediately before $\mathrm{Zn}^{2+}$ preincubation (mean \pm SEM of 3 oocytes).

the Ach-induced response was almost completely inhibited. In contrast to $\mathrm{Zn}^{2+}$ and $\mathrm{Cd}^{2+}, \mathrm{Ni}^{2+}$ had almost no ability to potentiate the $\mathrm{ACh}$ response. The maximal potentiation by $\mathrm{Ni}^{2+}$ was only to $112 \pm 5 \%$ of the response to ACh alone. Concentrations of $\mathrm{Ni}^{2+}$ at or above $1 \mathrm{~mm}$ inhibited the $\mathrm{ACh}$ response. 


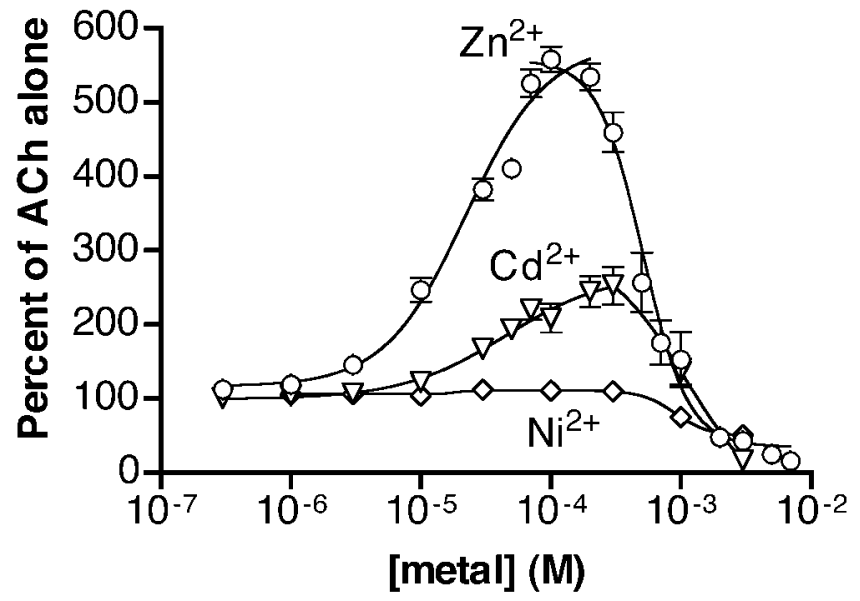

Figure 4. $\mathrm{Cd}^{2+}$ and $\mathrm{Ni}^{2+}$ are less effective than $\mathrm{Zn}^{2+}$ at potentiating neuronal nAChRs. The effects of $\mathrm{Cd}^{2+}(\nabla)$ and $\mathrm{Ni}^{2+}(\diamond)$ on ACh $(1$ $\mu \mathrm{M})$-induced current responses of $\alpha 4 \beta 4$-expressing oocytes are plotted as a percentage of the current obtained with $1 \mu \mathrm{M}$ ACh alone (mean \pm SEM of 3-5 oocytes). Potentiating and inhibiting phases were fit separately as described in Materials and Methods. Data from Figure $2 C$ showing the effect of $\mathrm{Zn}^{2+}(\bigcirc)$ are included for comparison. Some error bars are obscured by symbols.

\section{Potential involvement of histidine residues in mediating $\mathrm{Zn}^{2+}$ potentiation}

Histidine residues are often involved in coordinating $\mathrm{Zn}^{2+}$ at $\mathrm{Zn}^{2+}$ binding sites. DEPC, under some conditions ( $\mathrm{pH} \geq 6$, low millimolar concentrations), can selectively modify the imidazole ring of histidine, eliminating its ability to coordinate $\mathrm{Zn}^{2+}$ ions. We examined the effects of DEPC treatment on the ability of $\mathrm{Zn}^{2+}$ to modulate $\alpha 4 \beta 4$ and $\alpha 3 \beta 2$ receptors (Fig. 5). A $10 \mathrm{~min}$ incubation with DEPC concentrations ranging from $100 \mu \mathrm{M}$ to 3 mM had little effect on the response of $\alpha 4 \beta 4$ receptors to ACh. Although treatment with $100 \mu \mathrm{M}$ DEPC had a minimal effect on

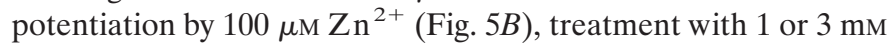
DEPC abolished the ability of $\mathrm{Zn}^{2+}$ to potentiate the $\alpha 4 \beta 4$ receptor (Fig. $5 A, B$ ). This result suggests the involvement of at least one histidine residue in mediating the potentiating effects of $\mathrm{Zn}^{2+}$ on neuronal nAChRs. We examined the effect of $3 \mathrm{~mm}$ DEPC on modulation of $\alpha 4 \beta 4$ receptors by a range of $\mathrm{Zn}^{2+}$ concentrations (Fig. $5 C$ ). Although potentiation was eliminated, $\mathrm{Zn}^{2+}$ continued to inhibit $\alpha 4 \beta 4$ receptors after DEPC treatment. DEPC ( $3 \mathrm{~mm}$ ) also failed to affect $\mathrm{Zn}^{2+}$ inhibition of $\alpha 3 \beta 2$ receptors (Fig. $5 D$ ). The ability of $\mathrm{Zn}^{2+}$ to inhibit $\alpha 4 \beta 4$ or $\alpha 3 \beta 2$ after DEPC treatment suggests that the inhibitory site on these receptors may not involve histidine residues.

To provide further evidence that histidine residues are involved in mediating $\mathrm{Zn}^{2+}$ potentiation of $\alpha 4 \beta 4$, we examined the effect of altering the $\mathrm{pH}$ (Fig. 6). At $\mathrm{pH} 5.5$, the extent of potentiation by $100 \mu \mathrm{M} \mathrm{Zn}^{2+}$ was significantly reduced (180 \pm $9 \%$ ) as compared with potentiation at $\mathrm{pH} 7.2$ (our standard conditions). Increasing the $\mathrm{pH}$ to 8.0 resulted in a significant increase in the magnitude of the $\mathrm{Zn}^{2+}$ effect $(770 \pm 70 \%)$. These results are consistent with a role for one or more histidine residues in mediating the potentiating effect of $\mathrm{Zn}^{2+}$.

\section{$\mathrm{Zn}^{2+}$-mediated potentiation and inhibition of neuronal nAChRs are voltage independent}

To assess the proximity of the $\mathrm{Zn}^{2+}$ binding sites to the electrical field of the membrane, we examined potentiation of $\alpha 4 \beta 4$ and inhibition of $\alpha 3 \beta 2$ receptors over a range of holding potentials.
A

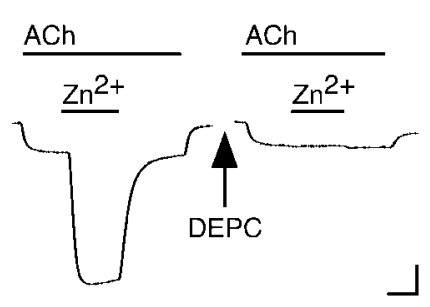

C

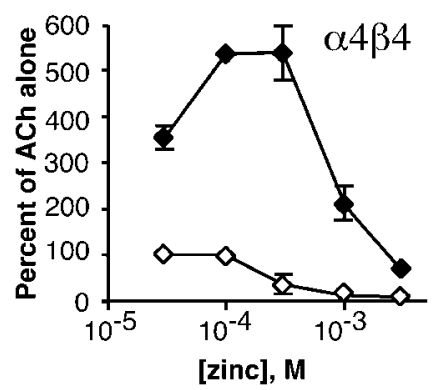

B

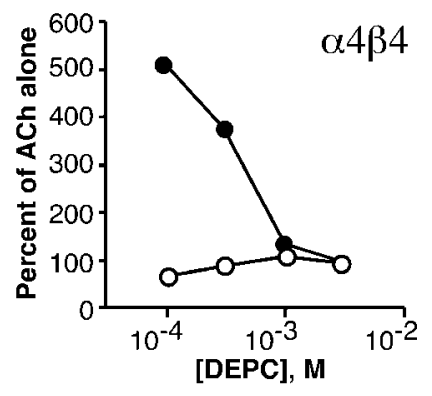

D



Figure 5. Diethylpyrocarbonate treatment abolishes $\mathrm{Zn}^{2+}$ potentiation but not $\mathrm{Zn}^{2+}$ inhibition of neuronal nAChRs. $A$, The current response of an $\alpha 4 \beta 4$-expressing oocyte to $1 \mu \mathrm{M}$ ACh before, during, and after coapplication of $100 \mu \mathrm{M} \mathrm{Zn}{ }^{2+}$ is shown on the left. After a 10 min treatment with $3 \mathrm{~mm}$ DEPC and a $10 \mathrm{~min}$ wash period, application of $100 \mu \mathrm{M} \mathrm{Zn}{ }^{2+}$ to the same oocyte no longer potentiates the ACh response (right trace). Calibration: $250 \mathrm{nA}, 20 \mathrm{sec}$. $B$, The effect of a $10 \mathrm{~min}$ incubation with various concentrations of DEPC on ACh $(1 \mu \mathrm{M})$-induced current responses in the presence of $100 \mu \mathrm{M} \mathrm{Zn}^{2+}(\mathbf{)})$ is plotted as a percentage of the response to $\mathrm{ACh}$ immediately before $\mathrm{Zn}^{2+}$ application. The effect of DEPC on current responses to $1 \mu \mathrm{M}$ ACh alone $(\bigcirc)$ is plotted as a percentage of the response to ACh before DEPC treatment. Symbols and error bars represent the mean \pm SEM of four sets of oocytes, each set consisting of three oocytes. Error bars are obscured by symbols. $C$, The effect of various concentrations of $\mathrm{Zn}^{2+}$ on the response of $\alpha 4 \beta 4$ receptors to $1 \mu \mathrm{M}$ ACh before $(\diamond)$ and after $(\diamond)$ treatment with $3 \mathrm{~mm} \mathrm{DEPC}$ is plotted as a percentage of the response to ACh alone immediately before $\mathrm{Zn}^{2+}$ application (mean \pm SEM of 3 oocytes). $D$, Block of $\alpha 3 \beta 2$-expressing oocytes by $1 \mathrm{~mm} \mathrm{Zn}^{2+}$ was measured before $(-)$ and after $(+)$ treatment with $3 \mathrm{~mm}$ DEPC for $10 \mathrm{~min}$ and is plotted as a percentage of the response to $4 \mu \mathrm{M} \mathrm{ACh}$ immediately before $\mathrm{Zn}^{2+}$ application (mean \pm SEM of 3 oocytes).

The potentiation of the ACh response of $\alpha 4 \beta 4$ receptors by $50 \mu \mathrm{M}$ $\mathrm{Zn}^{2+}$ was examined at several holding potentials ranging from $-90 \mathrm{mV}$ to $-40 \mathrm{mV}$ (Fig. $7 B$ ). This $\mathrm{Zn}^{2+}$ concentration was chosen to minimize any influence from the inhibition seen at higher $\mathrm{Zn}^{2+}$ concentrations. The extent of potentiation was similar at all holding potentials tested (Fig. $7 A, B$ ). The degree of inhibition of $\alpha 3 \beta 2 \mathrm{nAChR}$ current responses by $100 \mu \mathrm{M} \mathrm{Z \textrm {n } ^ { 2 + }}$ was also independent of the holding potential from $-90 \mathrm{mV}$ to $-40 \mathrm{mV}$ (Fig. 7B).

\section{$\mathrm{Zn}^{2+}$ potentiates the response of neuronal $\mathrm{nAChRs}$ to saturating acetylcholine concentrations}

We examined the effect of $\mathrm{Zn}^{2+}$ on the ACh concentrationresponse relationships of $\alpha 4 \beta 4$ and $\alpha 4 \beta 2$ receptors (see Materials and Methods). Again, $50 \mu \mathrm{M} \mathrm{Zn^{2+ }}$ was chosen to provide potentiation with minimal inhibition. $\mathrm{Zn}^{2+}$ coapplications significantly increased the response of $\alpha 4 \beta 4$ to saturating $\mathrm{ACh}$ concentrations $(160 \pm 11 \%$ of the response to $\mathrm{ACh}$ alone; $p<0.02)$ and significantly decreased the $\mathrm{EC}_{50}$ for $\mathrm{ACh}$ activation from $74 \pm 22$ 




Figure 6. $\mathrm{Zn}^{2+}$ potentiation of $\alpha 4 \beta 4$ is sensitive to alterations in $\mathrm{pH}$. Potentiation of the response to $1 \mu \mathrm{M}$ ACh by $100 \mu \mathrm{M} \mathrm{Zn^{2+ }}$ at pH 5.5, 7.2, and 8.0 is plotted as a percentage of the response to ACh alone (mean \pm SEM of 3 oocytes; significant differences from $\mathrm{pH} 7.2:{ }^{*} p<0.0001,{ }^{* *} p<$ $0.005)$.
A

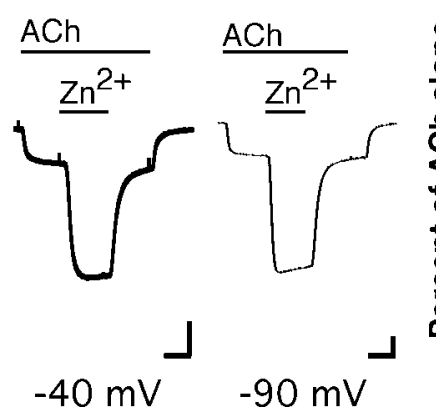

B



Figure 7. $\mathrm{Zn}^{2+}$ potentiation of $\alpha 4 \beta 4$ receptors and inhibition of $\alpha 3 \beta 2$ receptors are voltage independent. $A$, Current responses of an $\alpha 4 \beta 4$ expressing oocyte to $1 \mu \mathrm{M}$ ACh before, during, and after coapplication of $50 \mu \mathrm{M} \mathrm{Zn}{ }^{2+}$ at membrane holding potentials of $-40 \mathrm{mV}$ (left trace, calibration: $50 \mathrm{nA}, 20 \mathrm{sec}$ ) and $-90 \mathrm{mV}$ (right trace, calibration: $200 \mathrm{nA}$, $20 \mathrm{sec}$ ). The traces were normalized for comparison. $B$, Current responses of $\alpha 4 \beta 4$-expressing oocytes to $1 \mu \mathrm{M} \mathrm{ACh}$ in the presence of $50 \mu \mathrm{M} \mathrm{Zn}{ }^{2+}$ were recorded at various holding potentials and plotted as a percentage of the response to ACh alone (mean \pm SEM of 3 oocytes). Current responses of $\alpha 3 \beta 2$ expressing oocytes to $4 \mu \mathrm{M}$ ACh in the presence of 100 $\mu \mathrm{M} \mathrm{Zn}^{2+}$ were recorded at various holding potentials and plotted as a percentage of the response to $\mathrm{ACh}$ alone (mean \pm SEM of 3 oocytes).

$\mu \mathrm{M}$ in the absence of $\mathrm{Zn}^{2+}$ to $23 \pm 8 \mu \mathrm{M}$ in the presence of $\mathrm{Zn}^{2+}$ $(p<0.05)$ (Fig. 8A). $\mathrm{Zn}^{2+}$ coapplication also significantly increased the response of $\alpha 4 \beta 2$ to saturating ACh concentrations (140 $\pm 14 \%$ of the response to ACh alone; $p<0.02)$ but had no significant effect on the apparent ACh affinity of $\alpha 4 \beta 2$ (Fig. $8 B$ ).

\section{$\mathrm{Zn}^{2+}$ does not alter receptor desensitization rate}

One possible mechanism for $\mathrm{Zn}^{2+}$ potentiation is through an effect on receptor desensitization. If $\mathrm{Zn}^{2+}$ were to slow the desensitization rate of a receptor, an apparent potentiation of the agonist response would result. This possible mechanism seems unlikely to account for $\mathrm{Zn}^{2+}$ potentiation of $\alpha 4 \beta 4$, which can be dramatically potentiated even when no appreciable desensitization is evident (Fig. 1C). However, to examine this issue in more detail, we measured the desensitization rate of $\alpha 4 \beta 4$ and $\alpha 4 \beta 2$ receptors when exposed to an $\mathrm{EC}_{50}$ concentration of $\mathrm{ACh}$ in the absence and presence of $50 \mu \mathrm{M} \mathrm{Zn}^{2+}$. Oocytes were held at -40 $\mathrm{mV}$ and $\mathrm{Ba}^{2+}$ was substituted for $\mathrm{Ca}^{2+}$ in all solutions to mini-
A



B

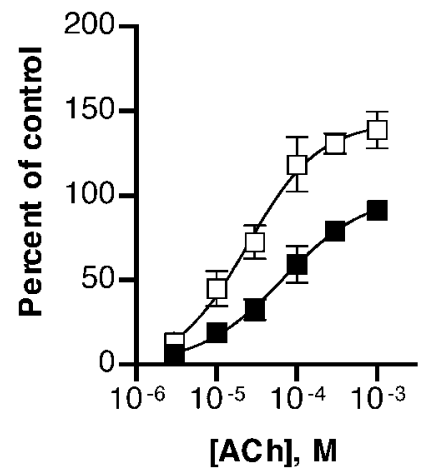

Figure 8. $\mathrm{Zn}^{2+}$ increases the response of neuronal nAChRs to saturating $\mathrm{ACh}$ concentrations. ACh concentration-response relationships of $\alpha 4 \beta 4$ - and $\alpha 4 \beta 2$-expressing oocytes in the absence (filled symbols) and presence (open symbols) of $50 \mu \mathrm{M} \mathrm{Zn^{2+ }}$ are plotted as a percentage of the fit maximum response to $\mathrm{ACh}$ alone (mean $\pm \mathrm{SEM}$ of 3 oocytes). $A$, $\mathrm{Zn}^{2+}(50 \mu \mathrm{M})$ significantly decreased the $\mathrm{EC}_{50}$ of $\alpha 4 \beta 4$ receptors for $\mathrm{ACh}$ from $74 \pm 22$ to $23 \pm 8 \mu \mathrm{M}(p<0.05)$ and significantly increased the maximal response to $160 \pm 11 \%$ of the maximal response to ACh alone $(p<0.02) . B, \mathrm{Zn}^{2+}(50 \mu \mathrm{M})$ significantly increased the maximal response of $\alpha 4 \beta 2$ receptors to $\mathrm{ACh}$ to $140 \pm 14 \%$ of the maximal response to $\mathrm{ACh}$ alone $(p<0.02)$.

mize the contribution of the $\mathrm{Ca}^{2+}$-activated $\mathrm{Cl}^{-}$channel (see Materials and Methods). For $\alpha 4 \beta 4$, there was no difference between desensitization rate for ACh alone $(\tau=88 \pm 13 \mathrm{sec})$ and the desensitization rate in the presence of $\mathrm{Zn}^{2+}(\tau=77 \pm 17 \mathrm{sec})$ $(n=6)$. For $\alpha 4 \beta 2$, there was no difference between the desensitization rate for ACh alone $(\tau=42 \pm 3 \mathrm{sec})$ and the desensitization rate in the presence of $\mathrm{Zn}^{2+}(\tau=43 \pm 7 \mathrm{sec})(n=5)$. We conclude that $\mathrm{Zn}^{2+}$ does not affect the rate of Ach-induced desensitization for these receptors.

\section{Determinants of $\mathrm{Zn}^{2+}$ potentiation are only partially localized to the $\mathrm{N}$-terminal extracellular domain}

We used chimeras of the $\alpha 3$ and $\alpha 4$ subunits to provide preliminary information regarding the location of amino acid residues involved in mediating $\mathrm{Zn}^{2+}$ potentiation (Fig. 9). The $\alpha 4-216-\alpha 3$ and $\alpha 3-216-\alpha 4$ subunits each consist of the N-terminal extracellular domain of one subunit joined to the remainder of the other subunit. Each of the chimeras was coexpressed with the $\beta 4$ subunit, and the resulting receptors were then examined for sensitivity to a range of $\mathrm{Zn}^{2+}$ concentrations using our standard protocol (see Materials and Methods). Receptors in which the $\mathrm{N}$-terminal extracellular domain of $\alpha 4$ has been replaced with the $\alpha 3$ sequence ( $\alpha 3-216-\alpha 4 \beta 4)$ showed a dramatic loss in sensitivity to $\mathrm{Zn}^{2+}$ potentiation. However, $170 \pm 5 \%$ potentiation at $100 \mu \mathrm{M}$ $\mathrm{Zn}^{2+}$ was still significantly greater than the potentiation seen with $\alpha 3 \beta 4$. Receptors in which the region of $\alpha 4$ containing the transmembrane and cytoplasmic domains has been replaced with the $\alpha 3$ sequence ( $\alpha 4-216-\alpha 3 \beta 4)$ also showed a loss in sensitivity to $\mathrm{Zn}^{2+}$ potentiation when compared with $\alpha 4 \beta 4$. However, with


$\alpha 4-216-\alpha 3 \beta 4$ receptors were potentiated to a greater degree than $\alpha 3-216-\alpha 4 \beta 4$ or $\alpha 3 \beta 4$ receptors. These results suggest that although the most critical determinants of $\mathrm{Zn}^{2+}$ potentiation are located in the $\mathrm{N}$-terminal extracellular domain of $\alpha 4$, important residues also reside in the remainder of the subunit. 


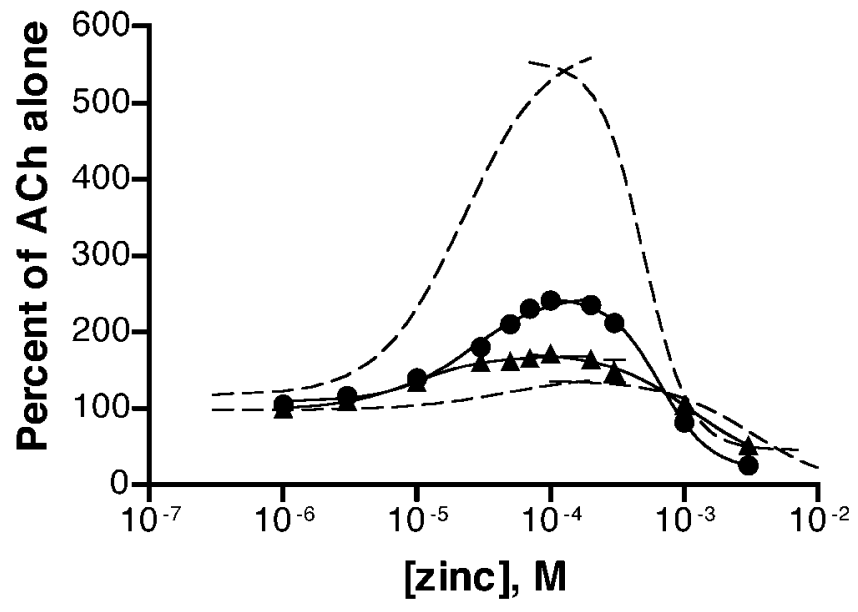

Figure 9. $\mathrm{Zn}^{2+}$ modulation of receptors formed by chimeric $\alpha$ subunits. The effects of $\mathrm{Zn}^{2+}$ coapplication on the Ach-induced current responses of $\alpha 4-216-\alpha 3 \beta 4(\mathbf{O})$ and $\alpha 3-216-\alpha 4 \beta 4(\mathbf{\Delta})$ receptors are plotted as a percentage of the response to ACh alone (mean \pm SEM of 3 oocytes). Some error bars are obscured by symbols. The potentiation and inhibition curves for $\alpha 4 \beta 4$ and $\alpha 3 \beta 4$ taken from Figure 2 are shown for comparison (dashed lines).

\section{DISCUSSION}

We have demonstrated that neuronal $\mathrm{nAChRs}$ are modulated by $\mathrm{Zn}^{2+}$ in a subunit-dependent manner. The $\alpha 2 \beta 2, \alpha 2 \beta 4, \alpha 3 \beta 4$, $\alpha 4 \beta 2$, and $\alpha 4 \beta 4$ receptors are potentiated by low $\mathrm{Zn}^{2+}$ concentrations (1-100 $\mu \mathrm{M})$ and inhibited by high concentrations of $\mathrm{Zn}^{2+}$ $(>100 \mu \mathrm{M})$. In contrast, the $\alpha 3 \beta 2$ receptors exhibit only inhibition of Ach-induced currents on $\mathrm{Zn}^{2+}$ coapplication. $\mathrm{Cd}^{2+}$ coapplication also modulated the $\mathrm{ACh}$ response of $\alpha 4 \beta 4$ receptors in a biphasic manner, but potentiation by $\mathrm{Cd}^{2+}$ was much less than that seen with $\mathrm{Zn}^{2+}$. A role for histidine residues in mediating $\mathrm{Zn}^{2+}$ potentiation was suggested by the ability of DEPC to abolish potentiation of $\alpha 4 \beta 4$ receptors and by the sensitivity of potentiation to alterations in $\mathrm{pH}$. $\mathrm{Zn}^{2+}$ coapplication potentiated the $\alpha 4 \beta 4$ and $\alpha 4 \beta 2$ receptors even at saturating ACh concentrations. However, $\mathrm{Zn}^{2+}$ had no effect on the rate of Ach-induced desensitization of either receptor.

$\mathrm{Zn}^{2+}$ has been shown to act as a subtype-dependent modulator of other classes of ligand-gated ion channels such as ATP, GABA, glutamate, and glycine receptors (Mayer et al., 1989; Rassendren et al., 1990; Cloues et al., 1993; Bloomenthal et al., 1994; Krishek et al., 1998; Harvey et al., 1999; Xiong et al., 1999; Laube et al., 2000). Within the glutamate and ATP receptor families, for example, some subtypes are modulated in a biphasic manner (showing potentiation, then inhibition as the $\mathrm{Zn}^{2+}$ concentration is increased), whereas others are inhibited only by $\mathrm{Zn}^{2+}$. This is similar to what we have observed with neuronal nAChRs. The effects of $\mathrm{Zn}^{2+}$ on NMDA-type glutamate receptors are particularly complex. Both voltage-dependent and voltage-independent inhibition as well as potentiation of NMDA receptors have been observed, depending on the particular receptor subunit combination, subunit splice variant, and $\mathrm{Zn}^{2+}$ concentration (Mayer et al., 1989; Hollmann et al., 1993; Paoletti et al., 1997; Traynelis et al., 1998).

Neuronal nAChRs have previously been shown to be potentiated by extracellular calcium (Mulle et al., 1992; Vernino et al., 1992). Calcium exerts its potentiating effect on neuronal nAChRs by increasing the probability of channel opening (Amador and Dani, 1995). Calcium appears to be bound by a series of EF-hand binding domains, and two critical glutamate residues on the $\alpha 7$ subunit have been identified (Galzi et al., 1996). These glutamate residues, as well as other components of the putative EF-hand structures, are conserved in the $\alpha$ and $\beta$ subunits used in our study. We think it is unlikely that $\mathrm{Zn}^{2+}$ potentiation operates through these $\mathrm{Ca}^{2+}$ binding sites for the following reasons. First, both $\alpha 7$ and $\alpha 3 \beta 2$ receptors are potentiated by $\mathrm{Ca}^{2+}$ and contain the putative EF-hand structures (Vernino et al., 1992; Galzi et al., 1996) but are not potentiated by $\mathrm{Zn}^{2+}$ (Palma et al., 1998) (Fig. $2 B)$. Second, the ability of DEPC and $\mathrm{pH}$ changes to reduce $\mathrm{Zn}^{2+}$ potentiation (Figs. 5, 6) suggests the involvement of histidine residues in coordinating $\mathrm{Zn}^{2+}$. Histidines are not generally found in EF-hand $\mathrm{Ca}^{2+}$ binding structures and are not present in the putative EF-hand structures in any of the subunits used in our study.

Neuronal nAChRs have also been shown to be modulated by various other agents. A group of compounds typified by physostigmine and galanthamine can activate exogenously expressed $\alpha 4 \beta 2$ receptors and $\alpha 7$-containing receptors expressed in hippocampal neurons by interacting with an allosteric site distinct from the ACh binding site (Pereira et al., 1993, 1994; Schrattenholz et al., 1996). Lead inhibits $\alpha 3 \beta 4$ and $\alpha 4 \beta 2$ receptors at submicromolar concentrations and potentiates $\alpha 3 \beta 2$ receptors at concentrations $>100 \mu \mathrm{M}$ (Zwart et al., 1995). Low concentrations (1-10 $\mu \mathrm{M})$ of $(+)$-tubocurarine potentiate $\beta 4$-containing receptors $(\alpha 2 \beta 4$ and $\alpha 3 \beta 4)$ while inhibiting $\beta 2$-containing receptors $(\alpha 2 \beta 2$ and $\alpha 3 \beta 2)$ (Cachelin and Rust, 1994). Atropine potentiates $\alpha 4 \beta 2$ and $\alpha 4 \beta 4$ receptors (but not $\alpha 2 \beta 2, \alpha 2 \beta 4, \alpha 3 \beta 2$, or $\alpha 3 \beta 4$ receptors) responding to low $(1 \mu \mathrm{M}) \mathrm{ACh}$ concentrations while inhibiting responses to high (1 mM) ACh concentrations (Zwart and Vijverberg, 1997). The pattern of potentiation and inhibition of the various receptor subtypes seen with these agents varies markedly from what we have found with $\mathrm{Zn}^{2+}$, suggesting that $\mathrm{Zn}^{2+}$ modulation of neuronal nAChRs is unrelated to modulation caused by these other agents.

We used DEPC to test for the involvement of histidine residues in $\mathrm{Zn}^{2+}$ potentiation of $\mathrm{nAChRs}$. Reaction of DEPC with histidine results in modification of the imidazole ring, rendering it incapable of coordinating $\mathrm{Zn}^{2+}$ (Miles, 1977; Lundblad and Noyes, 1984). A role for histidine residues in $\mathrm{Zn}^{2+}$ modulation of glycine receptors has been revealed using this technique (Harvey et al., 1999). DEPC can also affect arginine, lysine, cysteine, serine, and tyrosine residues when used under conditions of high concentration ( $\geq 10 \mathrm{~mm}$ ) and low $\mathrm{pH}(\mathrm{pH} 4)$. However, under our conditions ( $\leq 3 \mathrm{~mm}, \mathrm{pH} 7.2$ ), DEPC should be selective for histidine residues (Miles, 1977). We found that $\mathrm{Zn}^{2+}$ potentiation of neuronal $\mathrm{nAChRs}$ could be abolished by DEPC treatment. In contrast, $\mathrm{Zn}^{2+}$ continued to inhibit $\alpha 4 \beta 4$ and $\alpha 3 \beta 2$ after DEPC treatment.

Histidine residues are also prevented from coordinating $\mathrm{Zn}^{2+}$ by protonation of both imidazole nitrogens. The first $p K_{\mathrm{a}}$ ranges from 6.0 to 6.5 , depending on the local environment. If we assume a $p K_{\mathrm{a}}$ of 6.25 , then at $\mathrm{pH} 7.2$ (our standard conditions), $89 \%$ of the imidazole rings would have an unprotonated nitrogen capable of coordinating $\mathrm{Zn}^{2+}$. Shifting the $\mathrm{pH}$ below the $p K_{\mathrm{a}}$ would reduce the fraction of unprotonated histidines and should reduce histidine coordination of $\mathrm{Zn}^{2+}$. At $\mathrm{pH} 5.5$, at which only $18 \%$ of histidines would be unprotonated, potentiation of $\alpha 4 \beta 4$ was reduced to only $180 \pm 9 \%$ of ACh alone. At pH 8.0, at which $98 \%$ of histidine residues would be unprotonated, potentiation of $\alpha 4 \beta 4$ increased to $770 \pm 70 \%$ of $\mathrm{ACh}$ alone. The sensitivity of $\mathrm{Zn}^{2+}$ potentiation to both $\mathrm{DEPC}$ treatment and $\mathrm{pH}$ changes strongly 
suggests a role for histidine residues. These histidine residues may be involved in directly coordinating the $\mathrm{Zn}^{2+}$ ion. However, we cannot rule out the possibility that DEPC and changes in $\mathrm{pH}$ are affecting a histidine within an allosteric pathway through which $\mathrm{Zn}^{2+}$ might exert its potentiating effects.

To approximate the location of the $\mathrm{Zn}^{2+}$ binding sites in relation to the electric field of the membrane, we examined $\mathrm{Zn}^{2+}$ potentiation and inhibition at several holding potentials (Fig. 7). The degree of potentiation of $\alpha 4 \beta 4$ receptors and inhibition of $\alpha 3 \beta 2$ receptors remained constant across a range of holding potentials. This result suggests that potentiation and inhibition are not under the influence of the electric field of the membrane, and thus the relevant binding sites are not likely to be closely associated with the transmembrane domains of the receptor. We also examined the $\mathrm{Zn}^{2+}$ sensitivity of receptors formed by chimeras of the $\alpha 3$ and $\alpha 4$ subunits (Fig. 9). Results of these experiments suggest that determinants of $\mathrm{Zn}^{2+}$ potentiation are located within the N-terminal extracellular domain, as well as in the remainder of the protein.

It is clear that both $\alpha$ and $\beta$ subunits make contributions to $\mathrm{Zn}^{2+}$ potentiation of neuronal nAChRs. Possible explanations for this observation include a $\mathrm{Zn}^{2+}$ binding site on each individual subunit yielding five binding sites, or $\mathrm{Zn}^{2+}$ binding sites formed at the interface between $\alpha$ and $\beta$ subunits yielding at least two binding sites. The Hill coefficient values between 1.0 and 2.0 that we have observed for $\mathrm{Zn}^{2+}$ potentiation (Table 1) suggest that a neuronal $\mathrm{nAChR}$ may have one or two $\mathrm{Zn}^{2+}$ potentiation sites. If nAChRs have a single site, it might be similar to the $\mathrm{Ni}^{2+}$ binding site of retinal cyclic nucleotide-gated (CNG) channels (Shammat and Gordon, 1999). At least two subunits contribute a histidine residue to form a single $\mathrm{Ni}^{2+}$ site during the open state of the CNG channel (Gordon and Zagotta, 1995a,b). If neuronal nAChRs have two $\mathrm{Zn}^{2+}$ potentiation sites, the sites might be formed similarly to agonist binding sites (at the interface between two subunits). In either case, stabilization of the open state would explain our observation that $\mathrm{Zn}^{2+}$ increases the response to saturating $\mathrm{ACh}$ concentrations.

Knowledge regarding the effect of $\mathrm{Zn}^{2+}$ on neuronal nAChRs expressed in a neuronal context is limited. Nutter and Adams (1995) reported inhibition of ACh-evoked currents in cultured rat parasympathetic neurons. Although the neuronal nAChR subunit expression in these neurons is heterogeneous, the predominant subunits are $\alpha 3, \alpha 7$, and a varying ratio of $\beta 2$ and $\beta 4$ (Poth et al., 1996, 1997). Thus, based on our results and the results of Palma et al., (1998), many of the nAChRs expressed by these neurons would be expected to be inhibited by $\mathrm{Zn}^{2+}$.

CNS synaptic terminals have been shown to be capable of taking up, storing, and releasing $\mathrm{Zn}^{2+}$ (Huang, 1997; Frederickson et al., 2000). Extracellular $\mathrm{Zn}^{2+}$ is estimated to reach concentrations as high as several hundred micromolar during neuronal activity (Frederickson et al., 1983; Assaf and Chung, 1984). Neuronal nAChRs are located both presynaptically and postsynaptically in many parts of the CNS and PNS. Our finding that $\mathrm{Zn}^{2+}$ modulates neuronal nAChRs at concentrations that may be achieved in the nervous system suggests that $\mathrm{Zn}^{2+}$ may affect synaptic activity through modulation of neuronal nAChRs.

\section{REFERENCES}

Amador M, Dani JA (1995) Mechanism for modulation of nicotinic acetylcholine receptors that can influence synaptic transmission. J Neurosci 15:4525-4532.

Anand R, Conroy WG, Schoepfer R, Whiting P, Lindstrom J (1991) Neuronal nicotinic acetylcholine receptors expressed in Xenopus oo- cytes have a pentameric quaternary structure. J Biol Chem 266:11192-11198.

Assaf SY, Chung S-H (1984) Release of endogenous $\mathrm{Zn}^{2+}$ from brain tissue during activity. Nature 308:734-736.

Bloomenthal AB, Goldwater E, Pritchett DB, Harrison NL (1994) Biphasic modulation of the strychnine-sensitive glycine receptor by zinc. Mol Pharmacol 46:1156-1159.

Cachelin AB, Rust G (1994) Unusual pharmacology of (+)tubocurarine with rat neuronal nicotinic acetylcholine receptors containing $\beta 4$ subunits. Mol Pharmacol 46:1168-1174.

Chen D, Patrick JW (1997) The alpha-bungarotoxin-binding nicotinic acetylcholine receptor from rat brain contains only the alpha7 subunit. J Biol Chem 272:24024-24029.

Cloues R, Jones S, Brown DA (1993) Zinc potentiates ATP-activated currents in rat sympathetic neurons. Pflügers Arch 424:152-158.

Conroy WG, Berg DK (1995) Neurons can maintain multiple classes of nicotinic acetylcholine receptors distinguished by different subunit compositions. J Biol Chem 270:4424-4431.

Cooper E, Couturier S, Ballivet M (1991) Pentameric structure and subunit stoichiometry of a neuronal nicotinic acetylcholine receptor. Nature 350:235-238.

Corringer PJ, Le Novere N, Changeux JP (2000) Nicotinic receptors at the amino acid level. Annu Rev Pharmacol Toxicol 40:431-458.

Draguhn A, Verdorn TA, Ewert M, Seeburg PH, Sakmann B (1990) Functional and molecular distinction between recombinant rat GABA receptor subtypes by $\mathrm{Zn}^{2+}$. Neuron 5:781-788.

Drisdel RC, Green WN (2000) Neuronal $\alpha$-bungarotoxin receptors are $\alpha 7$ subunit homomers. J Neurosci 20:133-139.

Flores CM, Rogers SW, Pabreza LA, Wolfe BB, Kellar KJ (1992) A subtype of nicotinic cholinergic receptor in rat brain is composed of $\alpha 4$ and $\beta 2$ subunits and is up-regulated by chronic nicotine treatment. Mol Pharmacol 41:31-37.

Frederickson CJ, Klitenick MA, Manton WI, Kirkpatrick JB (1983) Cytoarchitectonic distribution of zinc in the hippocampus of man and the rat. Brain Res 273:335-339.

Frederickson CJ, Suh SW, Silva D, Frederickson CJ, Thompson RB (2000) Importance of zinc in the central nervous system: the zinccontaining neuron. J Nutr 130:1471S-1483S.

Galzi JL, Bertrand S, Corringer PJ, Changeux JP, Bertrand D (1996) Identification of calcium binding sites that regulate potentiation of a neuronal nicotinic acetylcholine receptor. EMBO J 15:5824-5832.

Gordon SE, Zagotta WN (1995a) A histidine residue associated with the gate of the cyclic nucleotide-activated channels in rod photoreceptors. Neuron 14:177-183.

Gordon SE, Zagotta WN (1995b) Subunit interactions in coordination of nickel in cyclic nucleotide-gated channels. Proc Natl Acad Sci USA 92:10222-10226.

Harvey SC, Maddox FN, Luetje CW (1996) Multiple determinants of dihydro- $\beta$-erythroidine sensitivity on rat neuronal nicotinic receptor $\alpha$ subunits. J Neurochem 67:1953-1959.

Harvey RJ, Thomas P, James CH, Wilderspin A, Smart TG (1999) Identification of an inhibitory $\mathrm{Zn}^{2+}$ binding site on the human glycine receptor $\alpha 1$ subunit. J Physiol (Lond) 520.1:53-64.

Hollmann M, Boulter J, Maron C, Beasley L, Sullivan J, Pecht G, Heinemann S (1993) Zinc potentiates agonist-induced currents at certain splice variants of the NMDA receptor. Neuron 10:943-954.

Howell GA, Welch MG, Frederickson CJ (1984) Stimulation-induced uptake and release of zinc in hippocampal slices. Nature 308:736-738.

Huang EP (1997) Metal ions and synaptic transmission: think zinc. Proc Natl Acad Sci USA 94:13386-13387.

Krishek BJ, Moss SJ, Smart TG (1998) Interaction of $\mathrm{H}^{+}$and $\mathrm{Zn}^{2+}$ on recombinant and native rat neuronal $\mathrm{GABA}_{\mathrm{A}}$ receptors. J Physiol (Lond) 507.3:639-652.

Laube B, Kuhse J, Betz H (2000) Kinetic and mutational analysis of $\mathrm{Zn}^{2+}$ modulation of recombinant human inhibitory glycine receptors. J Physiol (Lond) 522.2:215-230.

Lundblad RL, Noyes CM (1984) The modification of histidine residues. In: Chemical reagents for protein modification, pp 105-125. Boca Raton, FL: CRC.

Mayer ML, Vyklicky Jr L, Westbrook GL (1989) Modulation of excitatory amino acid receptors by group IIB metal cations in cultured mouse hippocampal neurones. J Physiol (Lond) 415:329-350.

Miles EW (1977) Modification of histidyl residues in proteins with diethylpyrocarbonate. Methods Enzymol 47:431-442.

Mulle C, Choquet D, Korn H, Changeux JP (1992) Calcium influx through nicotinic receptors in rat central neurons: its relevance to cellular regulation. Neuron 8:135-143.

Nutter TJ, Adams DJ (1995) Monovalent and divalent cation permeability and block of neuronal nicotinic receptor channels in rat parasympathetic ganglia. J Gen Physiol 105:701-723.

Palma E, Maggi L, Miledi R, Eusebi F (1998) Effects of $\mathrm{Zn}^{2+}$ on wild and mutant neuronal $\alpha 7$ nicotinic receptors. Proc Natl Acad Sci USA 95:10246-10250.

Paoletti P, Ascher P, Neyton J (1997) High-affinity zinc inhibition of NMDA NR1-NR2A receptors. J Neurosci 17:5711-5725. 
Pereira EFR, Reinhardt-Maelicke S, Schrattenholz A, Maelicke A, Albuquerque EX (1993) Identification and functional characterization of a new agonist site on nicotinic acetylcholine receptors of cultured hippocampal neurons. J Pharmacol Exp Ther 265:1474-1491.

Pereira EFR, Alkondon M, Reinhardt S, Maelicke A, Peng X, Lindstrom J, Whiting P, Albuquerque EX (1994) Physostigmine and galanthamine: probes for a novel binding site on the $\alpha 4 \beta 2$ subtype of neuronal nicotinic acetylcholine receptors stably expressed in fibroblast cells. J Pharmacol Exp Ther 270:768-778.

Poth K, Bookman RJ, Luetje CW (1996) Individual rat intrinsic cardiac neurons display variable nicotinic pharmacologies and neuronal nAChR $\beta$ subunit mRNA expression patterns. Soc Neurosci Abstr 22:1172.

Poth K, Nutter TJ, Cuevas J, Parker MJ, Adams DJ, Luetje CW (1997) Heterogeneity of nicotinic receptor class and subunit mRNA expression among individual parasympathetic neurons from rat intracardiac ganglia. J Neurosci 17:586-596.

Rassendren F-A, Lory P, Pin J-P, Nargeot J (1990) Zinc has opposite effects on NMDA and non-NMDA receptors expressed in Xenopus oocytes. Neuron 4:733-740.

Role LW (1992) Diversity in primary structure and function of neuronal nicotinic acetylcholine receptor channels. Curr Opin Neurobiol $2: 254-262$.

Schrattenholz A, Pereira EFR, Roth U, Weber KH, Albuquerque EX,
Maelicke A (1996) Agonist responses of neuronal nicotinic acetylcholine receptors are potentiated by a novel class of allosterically acting ligands. Mol Pharmacol 49:1-6.

Shammat IM, Gordon SE (1999) Stoichiometry and arrangement of subunits in rod cyclic nucleotide-gated channels. Neuron 23:809-819.

Traynelis SF, Burgess MF, Zheng F, Lyuboslavsky P, Powers JL (1998) Control of voltage-independent zinc inhibition of NMDA receptors by the NR1 subunit. J Neurosci 18:6163-6175.

Vernino S, Amador M, Luetje CW, Patrick J, Dani JA (1992) Calcium modulation and high calcium permeability of neuronal nicotinic acetylcholine receptors. Neuron 8:127-134.

Whiting PJ, Schoepfer R, Conroy WG, Gore MJ, Keyser KT, Shimasaki S, Esch F, Lindstrom JM (1991) Expression of nicotinic acetylcholine receptor subtypes in brain and retina. Brain Res Mol Brain Res 10:61-70.

Xiong K, Peoples RW, Montgomery JP, Chiang Y, Stewart RR, Weight FF, Li C (1999) Differential modulation by copper and zinc of P2X2 and P2X4 receptor function. J Neurophysiol 81:2088-2094.

Zwart R, Vijverberg HPM (1997) Potentiation and inhibition of neuronal nicotinic receptors by atropine: competitive and noncompetitive effects. Mol Pharmacol 52:886-895.

Zwart R, Van Kleef RGDM, Milikan JM, Oortgiesen M, Vijverberg HPM (1995) Potentiation and inhibition of subtypes of neuronal nicotinic acetylcholine receptors by $\mathrm{Pb}^{2+}$. Eur J Pharmacol 291:399-406. 